\title{
Characterization and Prognostication of Wastes Generated by Industries in Kampala Industrial and Business Park-Namanve
}

\author{
Timothy Omara ${ }^{1,2,3^{*}}$ (D), Nicodemus Othieno ${ }^{3,4}$, Jimmy Obonge ${ }^{3,4}$, Stephen Ssebulime ${ }^{2,5}$, \\ Moureen Kansiime ${ }^{2,6}$
}

${ }^{1}$ Department of Chemical Engineering, Faculty of Engineering and Informatics, University of Bradford, West Yorkshire, UK

${ }^{2}$ Department of Chemistry, Faculty of Science, Kyambogo University, Kampala, Uganda

${ }^{3}$ Department of Quality Control, Quality Assurance \& Product Development/Production, AgroWays Uganda

Limited, Jinja, Uganda

${ }^{4}$ Department of Chemical and Processing Engineering, Faculty of Engineering, Busitema University, Tororo, Uganda

${ }^{5}$ Directorate of Government Analytical Laboratory, Ministry of Internal Affairs, Kampala, Uganda

${ }^{6}$ Department of Quality Control and Quality Assurance, Hariss International Limited, Kampala, Uganda

Email: *prof.timo2018@gmail.com, othienonicodemus2@gmail.com,jimmyobonge@gmail.com,

stevemuyanja@yahoo.com,smolmomo2418@gmail.com

How to cite this paper: Omara, T., Othieno, N., Obonge, J., Ssebulime, S. and Kansiime, M. (2019) Characterization and Prognostication of Wastes Generated by Industries in Kampala Industrial and Business Park-Namanve. Open Access Library Journal, 6: e5189.

https://doi.org/10.4236/oalib.1105189

Received: January 18, 2019

Accepted: April 1, 2019

Published: April 4, 2019

Copyright $\odot 2019$ by author(s) and Open Access Library Inc.

This work is licensed under the Creative Commons Attribution International License (CC BY 4.0).

http://creativecommons.org/licenses/by/4.0/

\begin{abstract}
Kampala Industrial and Business Park (KIBP) features as the premier and the best planned industrial complex in Uganda's history that impacts the inner Murchison Bay of Lake Victoria. The number of operational establishments in the park has raised environmental concerns; air, land and water pollution are significantly magnified by the close proximity of industries. Furthermore, industrial trucks have created unprecedented traffic congestion on Kampala-Jinja highway because the highway design cannot accommodate the traffic. Industries are producing volumetric wastes, and rendering the surrounding areas unacceptable for residential, shopping and recreational purposes as previously proposed in the construction design. This cross-sectional study characterized the wastes being generated in the park and prospected the future generation trend of the wastes. Results indicate that 39 assorted types of wastes are being produced in KIBP. Annually, 3214.8 metric tons of wastes are produced in KIBP and this is prognosticated to triple in the next 5 years with new industries being set up. Chemical analysis revealed that $3 \%$ of the wastes currently generated are hazardous; $16 \%$ are non-biodegradable; $18 \%$ are metallic whereas the residual $63 \%$ are putrescible. Recycling of wastes should be encouraged to reduce the volume of wastes generated in KIBP.
\end{abstract}




\section{Subject Areas}

Chemical Engineering \& Technology, Environmental Sciences

\section{Keywords}

Characterization, Industrial Solid Waste, Namanve, Prognostication

\section{Introduction}

Industrial and business parks feature as pivotal sectors of development world over [1]. An industrial and business park is a portion of a city zoned primarily for industrial purposes majorly constituted by refineries, ports, warehouses, distribution centres and industries [2]. It is based on integration philosophy of various functions into a business area with products and services accompanied by reasonable economic turnover and job opportunities [1].

His Excellency, the president of the Republic of Uganda (Yoweri Kaguta Museveni) in an official message on $8^{\text {th }}$ February 2007 [3] recapped that point No. 5 of the National Resistance Movement (NRM) Ten-point programme worked out under his chairmanship and first published in 1986 [4] puts that NRM aims at "building an integrated, independent and self-sustaining economy". Further, he pointed that the country exports more than 3.5 million bags of unprocessed coffee, and 200,000 bales of unprocessed cotton, and imports processed juice from South Africa, and yet about 10 million metric tonnes of bananas are being used irrationally with $40 \%$ getting spoiled in storage [3]. The Planning Commission of the Ministry of Finance was thus mandated to among others set up industrial and business parks in Arua, Lira, Gulu, Soroti, Moroto, Mbale, Tororo, Jinja, Iganga, Masaka, Nakasongola, Luwero, Mbarara, Bushenyi, Kabale, Kasese, Fort Portal, Rakai, Mubende, Hoima and Kampala districts on approximately 500 acres of land and ensure access roads (tarmac), hydroelectricity and water are available [3].

Uganda Investment Authority (UIA), the statutory body responsible for investments in Uganda was mandated to instate twenty two (22) industrial and business parks (IBPs) throughout Uganda to generate employment as well as performing value addition to locally available goods and raw materials [3]. By and large, Luzira IBP, Bweyogerere IBP (where the National standards house of Uganda National Bureau of Standards is located), Jinja IBP, Kasese IBP, Soroti IBP, Mbale IBP, Karamoja IBP, Kashari Agricultural Land Mbarara Small Scale Entrepreneur's Park have been established [3] adding on KIBP-Namanve that was initiated in 1997 but was held back by underfunding of the credit agreement between Ugandan government and World Bank due to stiff resistance from environmentalists voicing against the wanton mowing down of the national eucalyptus forest in Namanve, administrative bureaucracy and inflated land costing [5]. 
Albeit all the efforts being factored into creating employment for the population in the unemployment-prone country, no much efforts have been injected to regulate the amount of wastes generated. In most industrial parks, little attention is paid to environmental concerns; industrialists discharge wastes into the environment before it is properly treated. At the time of this study, 40 investors operating in KIBP were poorly managing their industrial wastes [6], regrettably subjecting the park to pollution prone industrialization and its effects in the not-so-distant future. In the olden days, industries used to manage their wastes by direct discharge into the environment without prior treatment [7]. However, the current legal provision in Uganda mandates operational industries to either manage their own wastes appropriately or equivalently contract qualified companies to handle their generated wastes. Wagland and co-authors [7] pointed that minimization of waste generation, segregation and recycling of wastes is key in ensuring environmentally friendly industrialization. Further, fractions of non-hazardous industrial wastes can be harnessed to produce energy as Solid Refuse Fuel [8] and this has been attempted in Uganda [9]. Industries are constantly in need of details of the wastes they generate and it has been reported that some industries implementing good waste management practices realized large economic and environmental benefits [10]. Several published information on industrial wastes from industries around the world focused on waste characterization and management activities [11] [12] [13]. Hence, the primary step for planning, policy making, developing and budgeting a complete waste management system is to arrive at the quantum and composition of industrial wastes being generated [14].

There is finite published data on characterization of industrial solid wastes (ISWs) in Uganda. However, some authors have characterized municipal solid wastes generated majorly for the country's capital [15]. Other available information on industrial and municipal solid wastes generated in Uganda are routinely published by National Environmental Authority (NEMA) and the Uganda National Bureau of Statistics (UBOS) in their State of the Environment Report and Statistical Abstracts respectively. Recently, Nyende [16] performed a hydrogeological assessment for sustainable groundwater abstraction in KIBP-Namanve. The investigation established the behavioral response of groundwater system to increased abstraction. Pre-existing groundwater/borehole data in Namanve was harnessed to produce aquifer geometry, hydraulic properties and hydrogeological conceptual model of KIBP. The values were further manipulated whilst modelling to snugly fit the present hydraulic heads of Namanve. Subsequent modelling under non-pumping and pumping scenarios to match the current static water levels monitoring were performed and the results gave a mean recharge of $42 \mathrm{~mm} \cdot \mathrm{year}^{-1} \mathrm{~m} /$ day which reportedly maintains the natural equilibrium of non-pumping whereas with the pumping scenario, results pointed that the present estimated groundwater abstraction of $2871 \mathrm{~m}^{3} \cdot$ day $^{-1}$ in the area does not exert any appreciable effect on groundwater levels. An appreciable effect on water levels was countariwisely registered following an increment of the present 
abstraction rate by $500 \%[16]$.

To the best of our knowledge and basing on literature review, there is no data on the characterization of wastes generated by industries in KIBP-Namanve reported in open literature. Thus, this research was to quantify the total wastes generated in KIBP, characterize and predict the future waste generation trend by the currently operational and prospecting industries in the park.

\section{Materials and Method}

\subsection{Description of Area under Study}

Kampala Industrial and Business Park, referred to less commonly as Kampala Industrial Park, is a Ugandan IBP in Namanve, Bweyogerere Ward, Kiira Municipality, Wakiso District set up by UIA as the central industrial area for potential investors to start up industries, warehouses, distribution centers and other business offices [17] on 30-year renewable leases. It is one of the three industrial parks set up in greater Kampala Metropolitan area with others being Luzira IBP and Bweyogerere Industrial Estate [18]. It is approximately 15 kilometers, East of Metropolitan Kampala on Kampala-Jinja highway [19] at $0^{\circ} 20^{\prime} 35.0^{\prime \prime} \mathrm{N}, 32^{\circ} 41^{\prime} 55.0^{\prime \prime} \mathrm{E}$ (Latitude: 0.343050; Longitude: 32.698600) [20]. The highway passes through Namanve in an East to West direction, portioning it into North Namanve and South Namanve. Thus, the park is divided into four estates: the North estate located on the Northern side of the highway after Coca Cola plant and the South estate (constituted by South-A, South-B and South-C) on the opposite side with a network of murram and tarmac roads inadequately traversing the park (Figure $1)$.

The park, instated by the act of parliament in 1997 on an area of 894 acres was dominated by a national eucalyptus forest [21]. More than 200 investors were

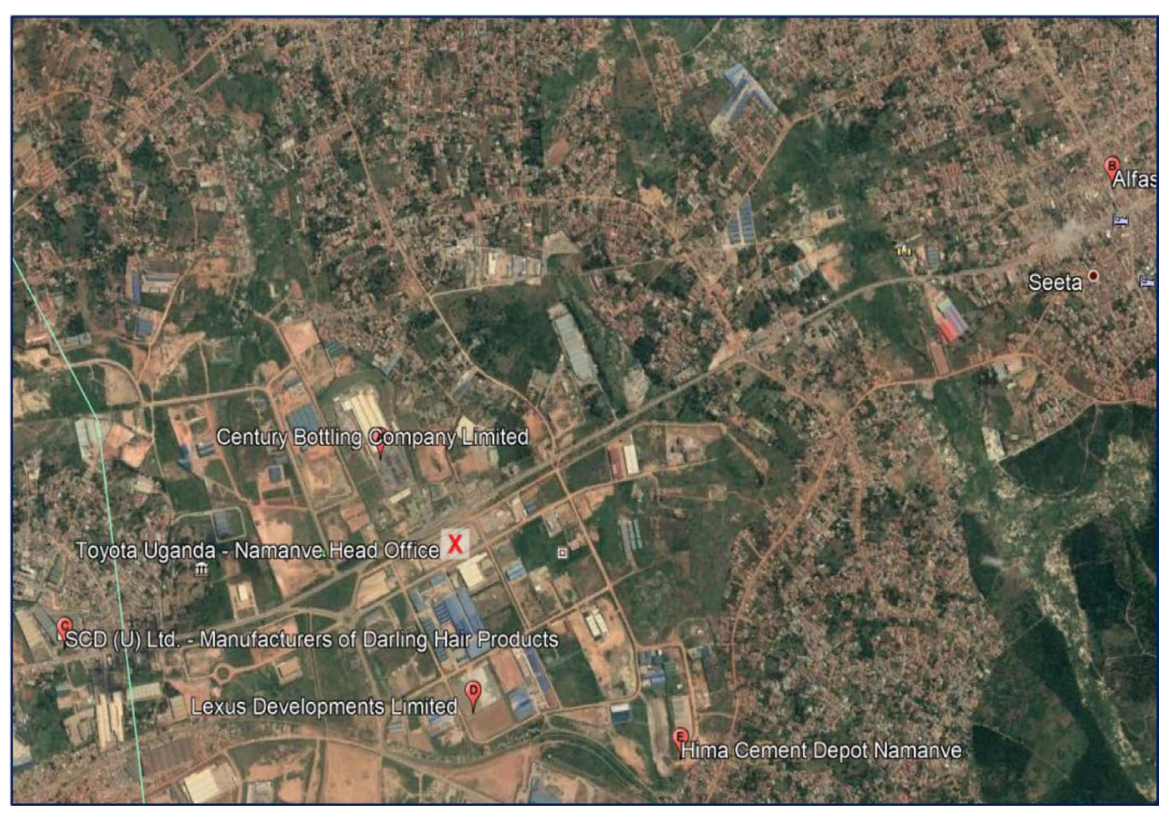

Figure 1. Kampala industrial and business park—Namanve. 
allocated land and space on concessional terms to install their investments. In August 2018, UIA announced that all the land in the park had been allocated to 290 prospective investors, of whom 192 (66.2\%) were Ugandan-based and 98 (33.8\%) were for foreigners. Currently, the park's size is 2200 acres with 33 operational industries. The mega establishments in KIBP-Namanve include: Century Bottling Company (a branch of the Coca Cola franchisee in Uganda), Three ways Shipping Limited, Leaf Tobacco and Commodities Limited, Roofings Rolling Mills, Hima Cement Limited (second-largest cement manufacturer in Uganda), Darling Hair and Cosmetics Limited, Interior Technologies, Azam, Steel and Tube industries, Toyota Uganda (Figure 2(a)), Yamaha Uganda, Regal Paints, Export Trading Company Limited, Victoria Seeds Limited, Kyagalanyi

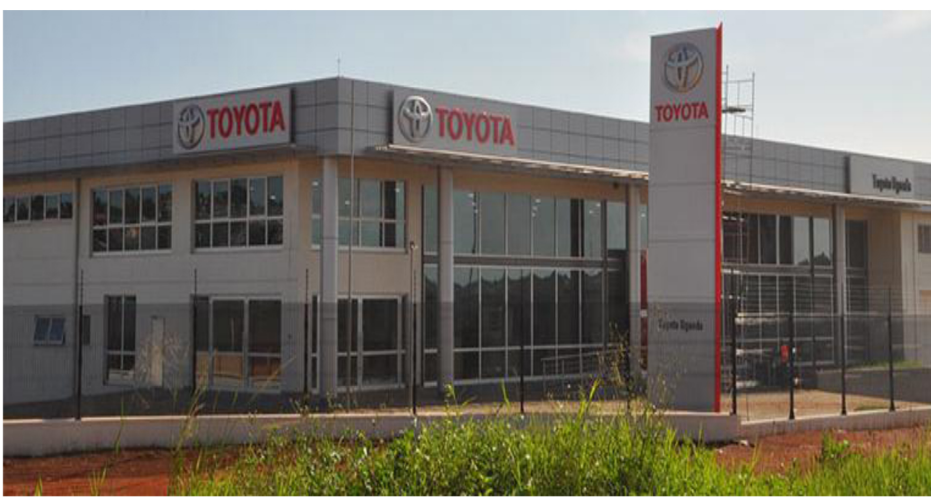

(a)

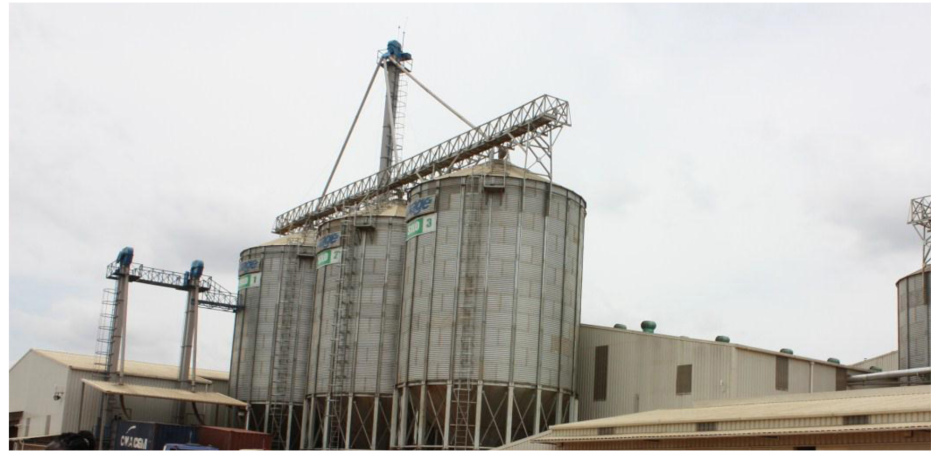

(b)

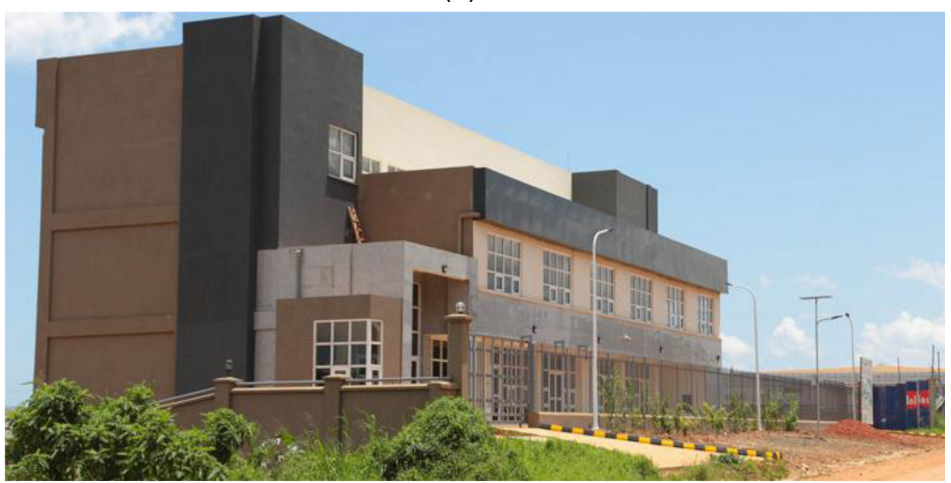

(c)

Figure 2. Some of the establishments in KIBP (a) Toyota Uganda; (b) Kyagulanyi coffee limited (c) DFCU financial centre. 
Coffee Limited (maintains a warehouse in the park with an going roasting plant installation) (Figure 2(b)), DFCU bank financial centre (Figure 2(c)), Rwenzori Mineral Water Bottling Company, Comesa-Namanve Industries, Orion Computers, Valley View Estates, Saba Gifco, Opit Investments, Sunbelt industries, Kingstone Enterprises, Roke Telecom, Happy Family Welders, Alfasan (the first and only veterinary medicine factory in Uganda), Luuka Plastics and Packaging, Fol Logistics, National Housing, Uganda Baati, Diamond Trust Bank, Red Pepper Publishing Company and Namanve Railway Station on the Uganda Railways System (administered by Rift Valley Railways Consortium) [21] [22] [23].

\subsection{Data Collection}

This study was a descriptive cross-sectional study based on field data gathered through questionnaires, review of Environmental Impact Assessment reports, interviews and visits to KIBP-Namanve from September 2016 to May 2017 [24]. Data on the availability of waste management facilities in the respective industries, waste collection and disposal as well as capacity of waste management authorities in managing different types of wastes in KIBP were collected. The 22 industries that participated in the study included Century Bottling Company, Rwenzori Bottling company, Fol Logistics, Roofings Rolling mills, Regal paints, Diamond Trust bank, Kyagulanyi Coffee Limited, Comesa-Namanve Industries, Orion Computers, Valley View Estates, Saba Gifco, Opit Investments, Victoria Seeds, Sunbelt industries, Three Ways Shipping, Kingstone Enterprises, Roke Telecom, Darling Hair and Cosmetics, Interior Technologies, Leaf Tobacco, Azam and Steel and Tube Industries.

\subsection{Stock Taking of Existing Industries and Establishing Their Quantum Waste Generation}

\subsubsection{Preliminary Field Visits}

This involved visits to KIBP and engaging in discussions with implementers (clients, contractors, consulting firms/engineers, UIA, sector heads and beneficiaries). Observation and recording was used as the data collection tool during this exercise.

\subsubsection{Interviews}

Face-to-face interviews were carried out to collect information about the current status of wastes generated and waste management in KIBP from the waste management departments in each industry and businesses operating in KIBP. Consultations and key informant interviews were done with project managers.

\subsubsection{Questionnaires}

"No survey is better than its questionnaires", the adage goes. Thus, industrial waste generation and handling data was also collected through questionnaire surveys. Several questionnaires were prepared and distributed among various industries and other businesses in KIBP to establish the current waste generation volume. Data collected focused on the type of wastes generated per industry, 
place of disposal, current status of waste collection site or facilities, mode of waste collection and expenses incurred in collection, distances covered to dispose the waste, quantity of wastes generated per day and per week.

\subsubsection{Review of Environmental Impact Assessment Reports}

Data was also obtained from Environmental Impact Assessment (EIA) reports. The data retrieved included: waste generation and management strategies, disposal facilities available, projected quantities of waste to be generated and mitigation measures to be taken in management of wastes.

\subsection{Data Analysis}

Analysis of data was done using Minitab statistical software (v18, Minitab Inc., USA) whereas graphical presentations were perfected using Microsoft Excel 2016.

\section{Results and Discussion}

\subsection{Current Waste Generation in KIBP and Waste Characterization}

The information obtained in this study provided an approximation of the quantity, characteristics and composition of wastes generated in KIBP. From the data collected (Table 1; Figure 3), about 61.65 metric tons of wastes are being generated weekly in KIBP and thus 3214.8 metric tons per year. The type of wastes produced varies from one industry to another and for this reason; waste management in KIBP is a complex task. The industrial solid wastes generated in KIBP were broadly classified into four major types: hazardous, biodegradable, non-biodegradable and metallic wastes basing on their content.

The results of this study has indicated that there is a significant potential for waste recycling and reuse in KIBP and this should be regarded [25]. Exactly 39 different types of industrial wastes are being generated by 22 industries and other businesses in the park; upto 25 types of these wastes can be recycled or reused.

Table 1. Quantum of wastes generated in Kampala industrial and business park.

\begin{tabular}{ccc}
\hline Type of Waste & $\begin{array}{c}\text { Average Quantity } \\
\text { Generated }(\mathrm{kg} / \mathrm{wk})^{\mathrm{a}}\end{array}$ & $\begin{array}{c}\text { Annual Quantity } \\
\text { Generated }(\mathrm{kg})^{\mathrm{b}}\end{array}$ \\
\hline Biodegradable & $38751.20 \pm 0.1265^{\mathrm{c}}$ & 2020598.28 \\
Non-biodegradable & $10087.50 \pm 0.1414^{\mathrm{d}}$ & 525991.071 \\
Metallic & $11140.00 \pm 1.6733^{\mathrm{e}}$ & 580871.428 \\
Hazardous & $1673.75 \pm 0.0234^{\mathrm{f}}$ & 87274.1071 \\
Total & 61652.45 & 3214734.89 \\
\hline
\end{tabular}

${ }^{\mathrm{a}} \mathrm{kg} / \mathrm{wk}$-kilogram per week, average quantity generated is presented as Mean \pm Standard Deviation, S.D of wastes generated for 26 successive weeks. Means within the same column that have alphabetical letters $\mathrm{c}$ to $\mathrm{f}$ are statistically different as determined by Tukey's HSD test. ${ }^{b}$ Annual waste generation was calculated by multiplying the average quantity of wastes generated per week by 52.1428571 weeks which constitute the weeks in a modern calendar year. 


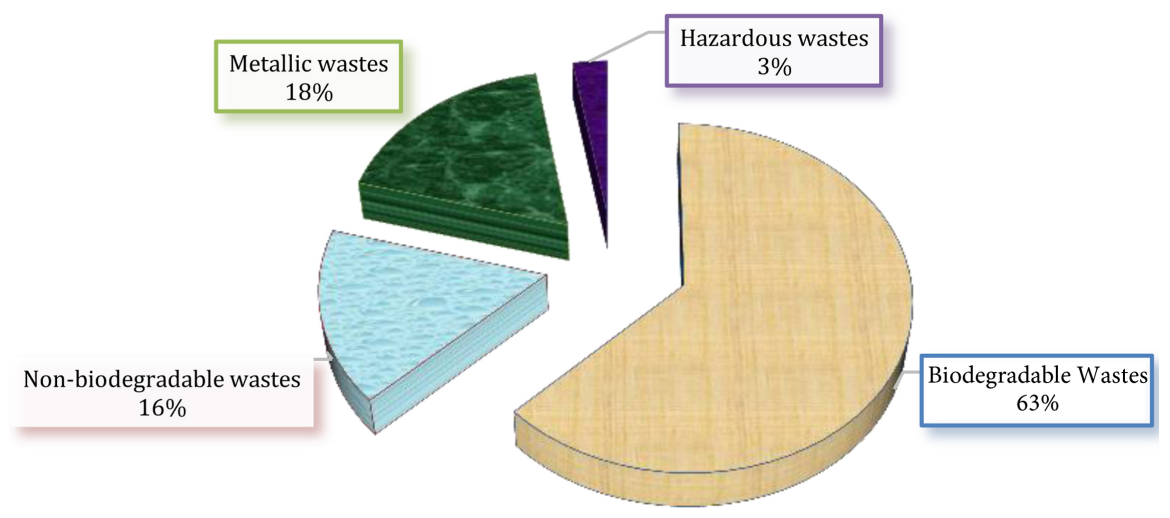

Figure 3. Quantum of wastes generated in KIBP per week (Table 1).

The categories of wastes belonging to the types above are given in Table 2 and illustrated in Figure 4. Categorization of wastes is advantageous for identification of risks and threats related to waste disposal which can be avoided by the knowledge of the types of wastes and identifying the opportunities for them. The quantity of industrial wastes generated in the industrial sector of some countries has been reported to depend on the structure of their economies. For instance, 18 million metric tons of industrial waste is produced every year by Taiwanian industries as reported by Mohamed et al. [26], 3 million metric tons per year of industrial wastes are produced by Chilean industries [27], 365.9 metric tons per year of wastes have been reported for industries in Arasanj industrial complex [14] and 1.1 billion metric tons in Shahroud Industrial Zone (SIZ) [28].

This study revealed that there is a significant volume (5\%) of waste paper and cardboard generated in KIBP. This could be due to the many operational industries dealing in paper work, presence of a newspaper publishing company (Red Pepper) and the recent move by the government to get rid of polythene bags (kaveera) especially for packaging ready-to-eat food items.

The volume of plastic wastes (6\%) recorded in KIBP can be attributed to the increased number of eateries that provide their customers with free polyethene bags, carrier bags, as well as the increased consumption of Polyethylene Terephphalate (PET) bottled mineral water, soft drinks (sodas, juices), ice creams and other eatables in recyclable PET containers [15]. In fact, all mineral water and a significant portion of soft drinks in Uganda are sold in PET bottles.

Metallic wastes constitute about $18 \%$ of the total wastes produced in KIBP. This is majorly from steel industries in the park such as Roofings Rolling Mills and Steel and Tube industries, metal fabrication workshops, automobile workshops and packaging materials such as metallic caps used for glass bottled sodas, beers and energy drinks and aluminium containers. The amount of metallic wastes reported in this study is actually less than in practice; the volume of metallic wastes produced in KIBP is considerately high. However, the availability of metal recycling industries implies that metal oddments are hot cakes following the recently heightened prices of metals on the world market. The demand for scrap metal is atypically high that increased incidences of theft of metal objects 
Table 2. Categories of wastes generated in Kampala industrial and business park per week.

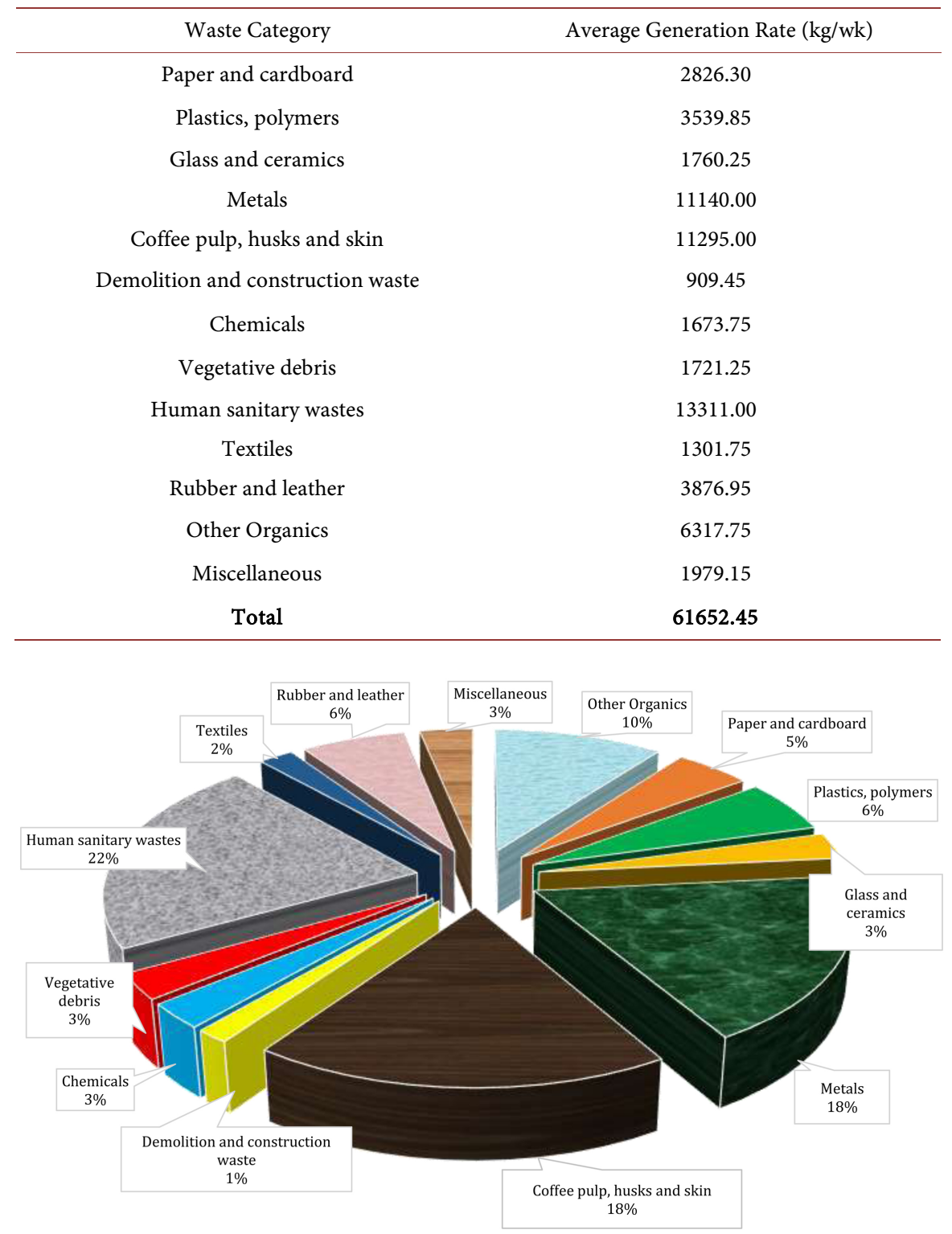

Figure 4. Categories of wastes generated in KIBP per week (Table 2).

such as manhole covers, road signs, railway sleepers, fences, guard rails, streetlights have been registered countrywide [29] [30].

Coffee wastes form a considerable (18\%) part of the wastes produced in KIBP. This is majorly from the coffeee processing plant of Kyagalanyi Coffee Limited. These wastes have so far been put to use.

Chemical wastes, representing $3 \%$ of the total wastes are hazardous and usually from food processing industries, paint industries and cement manufacture. These wastes present substantial or potential threats to human health or the environment due to their ability to ignite, react or otherwise cause corrosion or toxicity. These are mainly from Regal Paints, Centuring Bottling Company, Azam, Darling Hair and Cosmetics and Rwenzori Bottling Company. 
Demolition and construction wastes are mainly from the industries and roads being constructed and contribute $1 \%$ of the total wastes produced in KIBP.

Rubber and leather comes from the use of leather materials, rubber tyres, belts and equipment parts.

Textile wastes are from majorly small scale tailors, worn out uniforms and clothes.

Human sanitary wastes form a significant portion of wastes produced in KIBP as the current sanitary waste management system is poor. Namanve houses people of different ethnic origins and because of poor sanitary facilities, the park generates about $22 \%$ of the total wastes as sanitary wastes.

Glass and ceramic wastes are mainly from works necessitating use of glass and ceramics as glass doors, glass windows, tile roofs, floor tiles as well as glass parts of vehicles.

Vegetative debris (3\% of total wastes produced) are from destruction of vegetation to create space for industrial development as well as slashing activities to maintain industrial cleaniness. These wastes are however being composted or collected and transferred elsewhere outside the park.

\subsection{Waste Management in Kampala Industrial and Business Park}

One of the notable challenges of swift industrialization is the detrimental impacts of industrial wastes and for the case of Uganda, this has been exacerbated by the fact that most industries have been set up with little or no implementation of Environmental Impact Assessment or completion of mandatory periodical Environmental Audits (EA). Thus, a vast majority of industries lack an environmental management policy and environmental management plan for managing their generated wastes [30]. An integrated approach is thus inevitable in an attempt to manage and dispose volumetric quantities of diverse and contaminated mixtures of wastes as that produced in KIBP in an energy efficient and environmentally benign manner. Suitable management of industrial wastes is key to ensure that the wastes are treated and disposed of in a safe and economical manner [31] [32]. However, in the absence of an integrated waste management scheme, severe environmental issues such as soil water, and air pollution may result [33] [34].

Effective waste management requires subtle examination of the assorted steps in the life of the wastes including the raw materials for their manufacture, the manufacturing processes, design and fabrication of the finished products, their possible reuse and more importantly decision on their proper disposal. An integrated waste management system focuses on programming, organizing, maintaining and executing activities related to 1) source reduction; 2) possible reuse; 3) recycling; 4) landfill and gas-to-energy; 5) waste-to-energy conversion and (vi) sensitization and education on wastes management [35] [36] [37]. Out of the total generated industrial solid wastes in KIBP, 37\% are recycled, $10 \%$ are composted on site, $7 \%$ are landfilled, $3 \%$ are incinerated while $43 \%$ are collected and 
transferred outside the park (Table 3; Figure 5).

This research bewrayed that about 237.89 metric tons of ISWs generated in KIBP are annually sent to landfills. Land filling is currently the most readily available and most economical option for final disposal of solid wastes in developing countries. Nonetheless, it should be emphasized that it requires careful site selection to ward off possible adverse effects on public health or the environment as mismanagement of landfills may substantially pollute the air, surface and underground water. Leachate from landfills with high organics may also seep into a water body like River Namanve, thereby increasing its biochemical oxygen demand, chemical oxygen demand, $\mathrm{pH}$ and turbidity leading to suffocation of aquatic life. Additionally, organic matter may contain copious amounts of nitrogen and phosphorus, which on entering aquatic ecosystem may trigger eutrophication [38].

According to the data collected, collection and transfer of ISWs to other areas outside the park is the most preferred waste management approach in KIBP. This is a complex task because the wastes are not generated regularly. In order to

Table 3. Waste management approaches in Kampala industrial and business park- Namanve.

\begin{tabular}{ccc}
\hline Disposal Option & Average Quantity Disposed $(\mathrm{kg} / \text { week })^{\mathrm{a}}$ & Annual Quantity $(\mathrm{kg})$ \\
\hline Incineration & $1721.25 \pm 0.0231$ & 89750.8928 \\
Recycling & $22684.85 \pm 0.0173$ & 1182852.89 \\
Composting & $6317.75 \pm 0.0173$ & 329425.535 \\
Collection and Transfer & $26366.25 \pm 0.0058$ & 1374811.61 \\
Landfilling & $4562.35 \pm 0.0115$ & 237893.964 \\
Total & 61652.45 & 3214734.89 \\
\hline
\end{tabular}

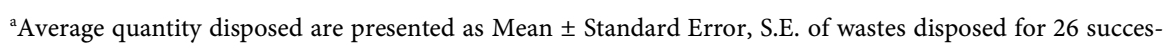
sive weeks.

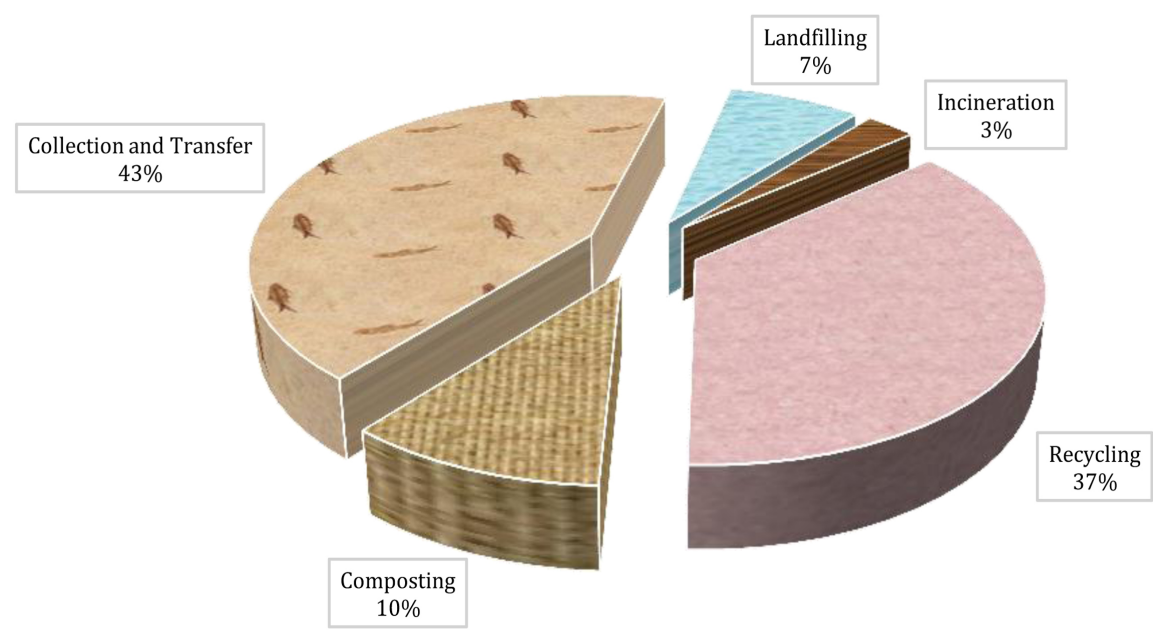

Figure 5. Waste management approaches in Kampala industrial and business park-Namanve. 
perform a proper collection and transfer of wastes, public health and safety must be considered. Wastes should be sorted to avoid mixing of hazardous and non-hazardous wastes.

Research findings show that KIBP has no modern central incineration plant. Therefore, about $3 \%$ of the total wastes generated in the park are incinerated by individual generators as no private firm has taken up the responsibility. This poses great challenge to the atmosphere because the gases emitted by the incinerators air are not regulated or pretreated. In addition, a significant amount of energy is lost during incineration which could be harnessed to generate more energy. Data collected in this concerted study indicate that $10 \%$ of the total wastes generated in the park is collected and composted. The commonest type of wastes composted is organic waste and this includes grass and other putrescible wastes which can decompose and be used as manure for farming. One of the immediate dangers of this method is pollution of air by gases such as methane, volatile organic compounds and carbon dioxide. In KIBP, about $37 \%$ of the total generated wastes are recycled. This is the greenest approach to waste management and majorly done for Polyethylene Terephthalate plastics and metal oddments. Some of the plastics are reused for packaging ready-to-drink locally prepared juices and boiled water.

\subsection{Prediction of Future Waste Generation in Kampala Industrial and Business Park}

At the time of this study, 22 industries and other businesses were operational within the park. The prospecting industries recorded were 87 in the construction phase while 120 were in the feasibility study stage [5] [23]. This gives a ratio of operational industries to prospecting industries as 1:3.95. This implies that the waste generation rate will at least triple when the prospecting 87 industries become operational in the next 5 years, the time estimated for their completion.

\section{Conclusion}

This research established that there are 22 operating industries in KIBP as per May 2017 and the annual waste generation volume stands at 3214.8 metric tons. Chemically, $3 \%$ of these wastes are hazardous; $16 \%$ are non-putrescible; $18 \%$ are metallic, whereas the residual $63 \%$ are putrescible. Lead and Chromium forms a greater percentage of hazardous wastes generated in KIBP. Waste reduction ought to be focused on as the priority principle in waste management in KIBP. Lack of robust data and capital are the major barriers to effective waste management in KIBP. Recycling and reuse of wastes should be done to reduce the volume of wastes generated. The current annual waste generation in KIBP will triple in the next 5 years as over 87 new industries are in the construction phase. National Environmental Authority and Uganda Investment Authority should monitor waste management by industries in KIBP as a total number of 272 mega establishments are expected at the completion of the third phase of KIBP con- 
struction. Uganda Investment Authority should devise mitigation measures to replenish the National Eucalyptus forest reserve in Namanve so as to blend industrial development through industrial park model with environmental conservation. National Water and Sewerage Cooperation should take up the central waste management responsibility in KIBP as previously proposed. Waste generation rates in other industrial parks should be estimated to ensure effective planning for waste collection, transportation and disposal.

\section{Acknowledgements}

We are grateful to Uganda Investment Authority and the stakeholders of the Industries in KIBP that participated in sessions that made this research successful.

\section{Conflicts of Interest}

The authors declare no conflicts of interest regarding the publication of this paper.

\section{References}

[1] Jarmila, V. (2010) Industrial Parks-History, Their Present and Influence on Employment. Review of Economic Perspectives, 10, 41-58. https://is.muni.cz/do/1456/soubory/aktivity/obzor/6182612/12878341/Industrial_pa rks_-_history_their_present_and_influence_on_employment.pdf https://doi.org/10.2478/v10135-009-0008-1

[2] James Chen. Industrial Parks. www.investopedia.com https://www.investopedia.com/terms/i/industrial-park.asp

[3] The Observer. A Million Jobs Forecast in 6 New Business Parks. https://observer.ug/news/headlines/56558-a-million-jobs-forecast-in-6-new-busines s-parks.html

[4] The National Resistance Movement (NRM) Ten-Point Programme. http://www.austria-uganda.at/dokumente/Ten-Point\%20Programme.pdf

[5] Daily Monitor. Ten Years on, Namanve Yet to Take off. https://www.monitor.co.ug/Business/Prosper/Ten-years-on--Namanve-yet-to-takeoff/688616-1729934-pcr4cuz/index.html

[6] The Daily Monitor. The Unending Tale of Kampala Industrial and Business Park. https://www.monitor.co.ug/Business/Prosper/Unending-tale-Kampala-Industrial-B usiness-Park/688616-3038460-w452sm/index.html

[7] Wagland, S.T., Veltre, F. and Longhurst, P.J. (2012) Development of An Image-Based Analysis Method to Determine the Physical Composition of a Mixed Waste Material. Waste Management, 32, 245-248.

https://doi.org/10.1016/j.wasman.2011.09.019

[8] Luoranen, M. and Horttanainen, M. (2007) Feasibility of Energy Recovery from Municipal Solid Waste in an Integrated Municipal Energy Supply and Waste Management System. Waste Management and Research, 25, 426-439. https://doi.org/10.1177/0734242X07076943

[9] Mboowa, D., Banadda, N., Kiggundu, N., Kabenge, I. and Komakech, A.J. (2015) Estimation of Methane Generation Based on Anaerobic Digestion and Mass Balance 
at Kiteezi Landfill, Kampala, Uganda. African Journal of Environmental Science and Technology, 9, 741-746. https://doi.org/10.5897/AJEST2015.1922

[10] Nasrullah, M., Vainikka, P., Hannula, J., Hurme, M. and Kärki, J. (2014) Mass, Energy and Material Balances of SRF Production Process Part 1: SRF Produced from Commercial and Industrial Waste. Waste Management, 34, 1398-1407. https://doi.org/10.1016/j.wasman.2014.03.011

[11] Curran, T. and Williams, I.D. (2012) A Zero Waste Vision for Industrial Networks in Europe. Journal of Hazardous Materials, 207-208, 3-7. https://doi.org/10.1016/j.jhazmat.2011.07.122

[12] Das, A., Gupta, A.K. and Mazumder, T.N. (2012) Vulnerability Assessment Using Hazard Potency for Regions Generating Industrial Hazardous Waste. Journal of Hazardous Materials, 209-210, 308-317. https://doi.org/10.1016/j.jhazmat.2012.01.025

[13] Maguyon, M.C.C., Alfafara, C.G., Migo,V.P., Movillon J.L. and Rebancos, C.M. (2012) Recovery of Copper from Spent Solid Printed Circuit-Board (PCB) Wastes of a PCB Manufacturing Facility by Two Step Sequential Acid Extraction and Electrochemical Deposition. Journal of Environmental Science and Management, 15, $17-27$.

http://jesam-uplb.org/article.php?aid=60-recovery-of-copper-from-spent-solid-prin ted-circuit-board--pcb--wastes-of-a-pcb-manufacturing-facility-by-two-step-seque ntial-acid-extraction-and-electrochemical-deposition

[14] Mazandaranizadeh, H., Koolivand, A., Binavapoor, M., Borujeni, F.G. and Soltani, R.D.C. (2017) Industrial Waste Characterization and Management in Arasanj Industrial Estate, Iran. Kuwait Journal of Science, 44, 104-111.

[15] Komakech, A.J., Banadda, N.E., Kinobe, J.R., Kasisira, L., Sundberg, C., Gebresenbet, G. and Vinnerås, B. (2014) Characterization of Municipal Waste in Kampala, Uganda. Journal of the Air \& Waste Management Association, 64, 340-348. https://doi.org/10.1080/10962247.2013.861373

[16] Nyende, J. (2018) A Preliminary Hydrological Assessment for Sustainable Groundwater Abstraction Using VES, MRS, SR and MODFLOW: A Case of Namanve Industrial and Business Park, Mukono District, Uganda. Journal of Earth Science and Climate Change, 9, 494.

[17] Kasemiire, C. (2018) No More Land in Namanve Industrial Park, Says UIA. Daily Monitor, Kampala.

[18] Uganda 7. Government Talks Tough over Industrial Park Land. https://uganda7.com/info/government-talks-tough-over-industrial-park-land/

[19] Globefeed.com. Distance between Post Office Building, Kampala Road, Kampala, Uganda and Namanve Industrial Park, Kampala-Jinja Highway, Uganda. https://distancecalculator.globefeed.com/Uganda_Distance_Result.asp?fromplace= Post\%20Office\%20Building\%2C\%20Kampala\%20Road\%2C\%20Kampala\%2C\%20U ganda\&toplace=Namave\%20Industrial\%20Park\%2C\%20Kampala-Jinja\%2C\%20Ugand a\&dt1=ChIJXyfX9IC8fRcRorrkbY-nufI\&dt2=ChIJjakXW0K4fRcR3RiO3ljyJ0Q\&sr= $\underline{\mathrm{dc}}$

[20] Google Maps. Location of Kampala Industrial and Business Park. Namanve, Uganda.

https://www.google.com/maps/place/0\%C2\%B020'35.0\%22N+32\%C2\%B041'55.0\%2 2E/@0.3677259,32.6927574,12z/data=!4m5!3m4!1s0x0:0x0!8m2!3d0.3430556!4d32.6 986111 
[21] The Daily Monitor. Namanve and Sonde Becomes More Attractive as Population Shoots up.

https://mobile.monitor.co.ug/magazines/Namanve-and-Ssonde-become-more-attra ctive/691254-1852476-format-xhtml-3vlwqc/index.html

[22] Kampala Industrial and Business Park.

https://en.wikipedia.org/wiki/Kampala_Industrial_and_Business_Park

[23] KIBP Media Tour. Uganda Investment Authority. http://www.ugandainvest.go.ug/wp-content/uploads/2016/03/KIBP-Media-Tour-M arch-2016.pdf

[24] Mansoorian, H.J., Yari, A.R., Rajabizadeh, A., Dowlatshahi, S.H., Khanjani, N. and Hatami, B. (2013) Hazardous and Industrial Wastes Management: A Case Study of Khazra Industrial Park, Kerman. Archives of Hygiene Sciences, 2, 79-90.

http://jhygiene.muq.ac.ir/article-1-14-en.pdf

[25] Memon, M.A. (2010) Integrated Solid Waste Management Based on the 3R Approach. Journal of Material Cycles and Waste Management, 12, 30-40. https://doi.org/10.1007/s10163-009-0274-0

[26] Mohamed, A.F., Wang, M.A., Hassan M.N. and Jaafar, A.B. (2008) Ecosystem Approach for Sustainable Industrial Hazardous Waste Management in Malaysia. Environmental Research Journal, 2, 306-310. http://docsdrive.com/pdfs/medwelljournals/erj/2008/306-310.pdf

[27] Navia, R. and Bezama, A. (2008) Hazardous Waste Management in Chilean Main Industry: An Overview. Journal of Hazardous Materials, 158, 177-184. https://doi.org/10.1016/j.jhazmat.2008.01.071

[28] Saeid, N., Roudbari, A. and Yaghmaeian, K. (2014) Design and Implementation of Integrated Solid Wastes Management Pattern in Industrial Zones, Case Study of Shahroud, Iran. Journal of Environmental Health Science \& Engineering, 12, 32. https://doi.org/10.1186/2052-336X-12-32

[29] The Daily Monitor. Open Manholes: The Graves Ready to Devour You Alive. https://www.monitor.co.ug/SpecialReports/Open-manholes--The-graves-ready-to-d evour-you-alive/688342-2630308-x5pq2j/index.html

[30] Uganda Radio Network. Arua Town Residents Accused of Stealing Manhole Covers.

https://ugandaradionetwork.com/story/arua-town-residents-accused-of-stealing-ma nhole-covers

[31] Walakira, P. and Okot-Okumu, J. (2011) Impact of Industrial Effluents on Water Quality of Streams in Nakawa-Ntinda, Uganda. Journal of Applied Science and Environmental Management, 15, 289-296. http://www.bioline.org.br/pdf?ja11050 https://doi.org/10.4314/jasem.v15i2.68512

[32] Roy, W.Y., Asem, S.O. and Al-Burais, M. (2015) Crude Oil Contamination on the Sabkha Facies of Kuwait. The Kuwait Journal of Science, 42, 191-209. https://journalskuwait.org/kjs/index.php/KJS/article/view/528

[33] Duane, M.J. (2014) 19th Century Lignite Mining (Germany): Hazards from Non-Ideal Waste Sequestration. The Kuwait Journal of Science, 41, 191-202. https://journalskuwait.org/kjs/index.php/KJS/article/view/244

[34] Oluremi, J.R., Coker, A.O., Sridhar, M.K.C. and Olaoye, R.A. (2013) Solid Waste Management in a Leprosarium in Southwestern Nigeria. Civil and Environmental Research, 3, 98-106.

https://www.iiste.org/Journals/index.php/CER/article/view/7733/7648

[35] Usapein, P. and Chavalparit, O. (2014) Options for Sustainable Industrial Waste 
Management Toward Zero Landfill Waste in a High-Density Polyethylene (HDPE) Factory in Thailand. Journal of Material Cycles and Waste Management, 16, 373-383. https://doi.org/10.1007/s10163-013-0198-6

[36] Mrayyan, B. and Hamdi, M.R. (2006) Management Approaches to Integrated Solid Waste in Industrialized Zones in Jordan: A Case of Zarqa City. Waste Management, 26, 195-205. https://doi.org/10.1016/j.wasman.2005.06.008

[37] Grodzinska-Jurczak, M. (2001) Management of Industrial and Municipal Solid Wastes in Poland. Resources. Conservation and Recycling, 32, 85-103. https://doi.org/10.1016/S0921-3449(00)00097-5

[38] Nakibuuka, M.M., Tashobya, D., Banadda, N., Fildah Ayaa, F., Nhapi, I., Garba, U.W. and Kimwaga, R. (2015) Qualitative Determination of Methane Gas at Selected Sites in Kampala City, Uganda. The Open Environmental Engineering Journal, 5, 50-55. https://benthamopen.com/ABSTRACT/TOENVIEJ-5-50 https://doi.org/10.2174/1874829501205010050 